Article

\title{
Anti-Inflammatory Comparison of Melatonin and Its Bromobenzoylamide Derivatives in Lipopolysaccharide (LPS)-Induced RAW 264.7 Cells and Croton Oil-Induced Mice Ear Edema
}

\author{
Pimpichaya Sangchart ${ }^{1}$, Panyada Panyatip ${ }^{2}$ (D), Teerasak Damrongrungruang ${ }^{2,3}$, Aroonsri Priprem ${ }^{4}$, \\ Pramote Mahakunakorn ${ }^{2,5}$ and Ploenthip Puthongking 2,6,*(D)
}

Citation: Sangchart, P.; Panyatip, P.; Damrongrungruang, T.; Priprem, A.; Mahakunakorn, P.; Puthongking, P. Anti-Inflammatory Comparison of Melatonin and Its

Bromobenzoylamide Derivatives in Lipopolysaccharide (LPS)-Induced RAW 264.7 Cells and Croton Oil-Induced Mice Ear Edema. Molecules 2021, 26, 4285. https:// doi.org/10.3390/molecules26144285

Academic Editor: Francesco Epifano

Received: 31 May 2021

Accepted: 13 July 2021

Published: 15 July 2021

Publisher's Note: MDPI stays neutral with regard to jurisdictional claims in published maps and institutional affiliations.

Copyright: (c) 2021 by the authors. Licensee MDPI, Basel, Switzerland. This article is an open access article distributed under the terms and conditions of the Creative Commons Attribution (CC BY) license (https:// creativecommons.org/licenses/by/ $4.0 /)$.
1 Graduate School, Khon Kaen University, Khon Kaen 40002, Thailand; pimpichaya@kkumail.com

2 Melatonin Research Group, Faculty of Pharmaceutical Sciences, Khon Kaen University, Khon Kaen 40002 , Thailand; ppanyada90@gmail.com (P.P.); dteera@kku.ac.th (T.D.); pramah@kku.ac.th (P.M.)

3 Division of Oral Diagnosis, Department of Oral Biomedical Sciences, Faculty of Dentistry, Khon Kaen University, Khon Kaen 40002, Thailand

4 Faculty of Pharmacy, Mahasarakham University, Maha Sarakham 44150, Thailand; aroonsri@kku.ac.th

5 Department of Pharmacognosy and Toxicology, Faculty of Pharmaceutical Sciences, Khon Kaen University, Khon Kaen 40002, Thailand

6 Department of Pharmaceutical Chemistry, Faculty of Pharmaceutical Sciences, Khon Kaen University, Khon Kaen 40002, Thailand

* Correspondence: pploenthip@kku.ac.th; Tel.: +66-43-203149

Abstract: The pineal gland is a neuroendocrine organ that plays an important role in anti-inflammation through the hormone melatonin. The anti-inflammatory effects of melatonin and its derivatives have been reported in both in vitro and in vivo models. Our previous study reported the potent antioxidant and neuroprotective activities of bromobenzoylamide substituted melatonin. In silico analysis successfully predicted that melatonin bromobenzoylamid derivatives were protected from metabolism by CYP2A1, which is a key enzyme of the melatonin metabolism process. Therefore, the anti-inflammatory activities of melatonin and its bromobenzoylamide derivatives BBM and EBM were investigated in LPS-induced RAW 264.7 macrophages and croton oil-induced ear edema in mice. The experiments showed that BBM and EBM significantly reduced production of the inflammatory mediators interleukin-6 (IL-6), prostaglandin E2 ( $\left.\mathrm{PGE}_{2}\right)$, and nitric oxide (NO) in a dose-dependent manner, but only slightly affected TNF- $\alpha$ in LPS-induced RAW 264.7 macrophages. This suggests that modifying melatonin at either the N1-position or the $N$-acetyl side chain affected production of NO, $\mathrm{PGE}_{2}$ and IL-6 in in vitro model. In the croton oil-induced mouse ear edema model, BBM, significantly decreased ear edema thickness at 2-4 h. It leads to conclude that bromobenzoylamide derivatives of melatonin may be one of the potential candidates for a new type of anti-inflammatory agent.

Keywords: melatonin; amide derivative; anti-inflammation; RAW 264.7 cells; LPS; mice ear edema

\section{Introduction}

Inflammation is a defense mechanism against pathogens. It is a complex process involving multiple cell types and mediators. Macrophages play an important role in the inflammatory response to pathogens by releasing pro-inflammatory mediators, including tumor necrosis factor- $\alpha$ (TNF- $\alpha$ ), interleukin (IL)-1 $\beta$, IL-6, cyclooxygenase (COX)-2, and nitric oxide (NO) [1]. Overproduction of these mediators and non-resolution of inflammation leads to the pathophysiology of many chronic inflammatory diseases, such as rheumatoid arthritis (RA), systemic lupus erythematosus (SLE), chronic obstructive pulmonary disease (COPD), Crohn's disease, ulcerative colitis and some neurodegenerative diseases [2].

Melatonin and its metabolites, N1-acetyl-N2-formyl-5-methoxykynuramine (AFMK) and N1-acetyl-5-methoxykynuramine (AMK), have antioxidant and anti-inflammatory 
activities. They are highly efficient NO scavengers [3-6], and melatonin has been shown to reduce the production of pro-inflammatory cytokines such as interferon gamma (IF- $\gamma$ ), TNF$\alpha$, IL- $1 \beta$, and IL- 6 , inhibit NO production, and suppress inducible nitric oxide synthase (iNOS) and COX-2 gene expression $[4,7,8]$. Melatonin has also been shown to exhibit antiinflammatory effects in vivo [9-11]. Although melatonin has low toxicity, its usefulness is limited by its short half-life and low oral bioavailability [12-15]. Therefore, several synthetic melatonin derivatives that retain melatonin's bioactivities but improve upon these limitations have been developed [7,16-19]. $\mathrm{N}$-amide melatonin derivatives that mimic the indole ring residue of Non-Steroidal Anti-Inflammatory Drugs (NSAIDs) were synthesized by our group (Figure 1). The derivatives with bromobenzoylamide-substitutions had higher antioxidant capacity than unsubstituted derivatives, and this affected the electron spin resonance (ESR) signal [20]. This result is supported by the study of Mor et al. who showed that increasing lipophilicity at the indole ring of melatonin improved antioxidant activity [21]. It is well known that inflammation processes are related to increases in free radicals such as reactive oxygen species (ROS) [6].

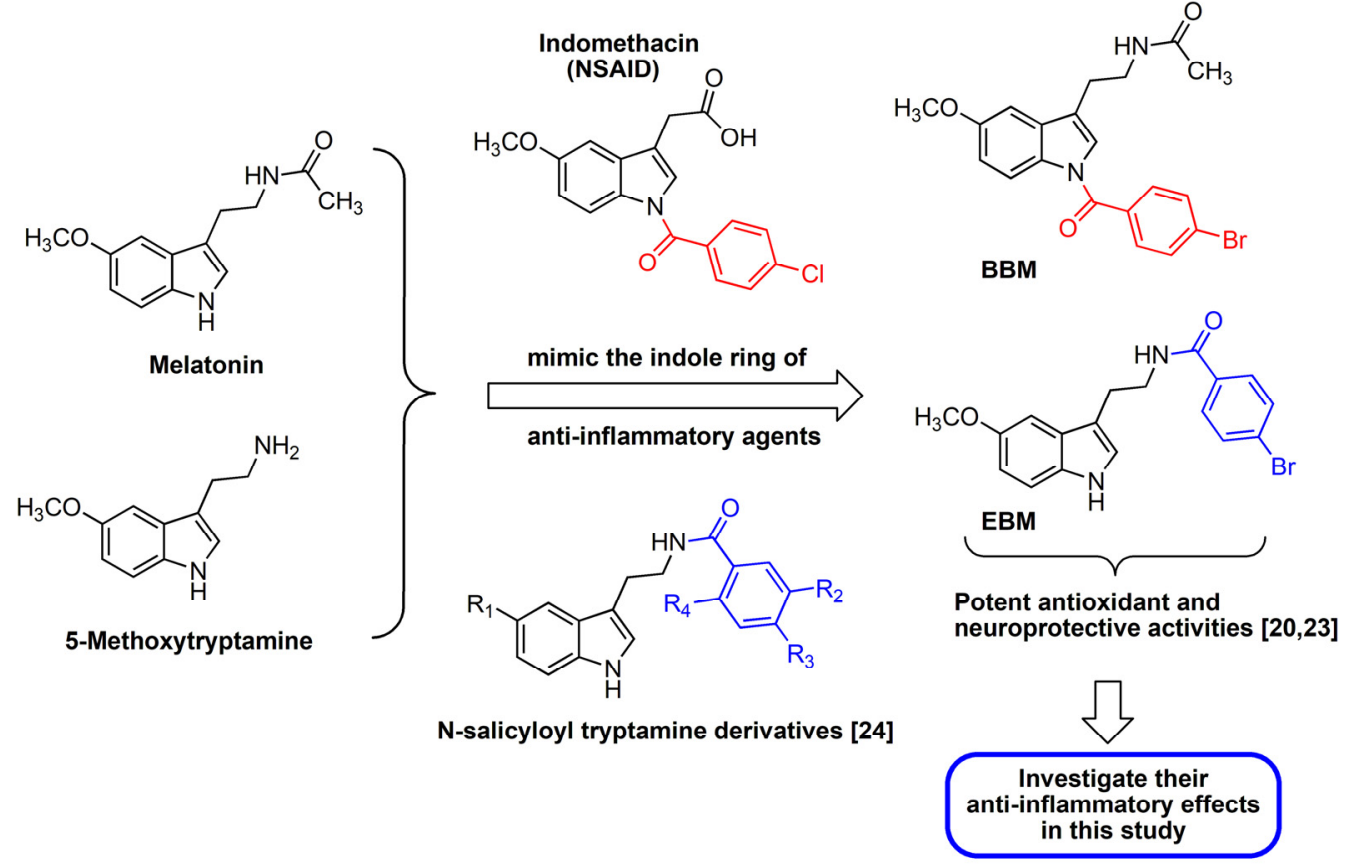

Figure 1. Design of the target compounds; BBM and EBM.

Interestingly, an in silico study predicted that the N1-position lipophilic-substituted melatonin derivative ( $N$-(2-(1-4-bromobenzoyl-5-methoxy-1H-indol-3-yl)ethyl) acetamide, BBM) could not be metabolized by CYP1A2, which prolonged its half-life compared with melatonin [22]. In contrast, while another melatonin derivative with a 4-bromobenzoyl amide substitution at the $\mathrm{N}$-acyl side chain (4-bromo- $N$-(2-(5-methoxy-1H-indol-3-yl)ethyl) benzamide, EBM) was predicted to be a substrate of CYP1A2, it displayed a potent antioxidant and neuroprotective effect $[20,23]$. Fan et al. [24] also reported that $N$-salicyloyl tryptamine derivatives are potential anti-neuroinflammation agents that act by decreasing the production of proinflammatory mediators, $\mathrm{NO}, \mathrm{PGE}_{2}$ and TNF- $\alpha$. These considerations prompted us to investigate and evaluate the anti-inflammatory activity of the BBM and EBM lipophilic melatonin derivatives. The present study compared the inhibitory effects of BBM and EBM with melatonin on inflammation mediators such as NO, PGE 2 , IL-6 and TNF- $\alpha$ in LPS-induced RAW 264.7 macrophages and on acute inflammation in vivo in croton oil-induced mouse ear edema. The synthesis and structure elucidation of BBM and EBM have been previously described [20]. The molecular information is shown in the Supplementary Material (Figures S1-S6). 


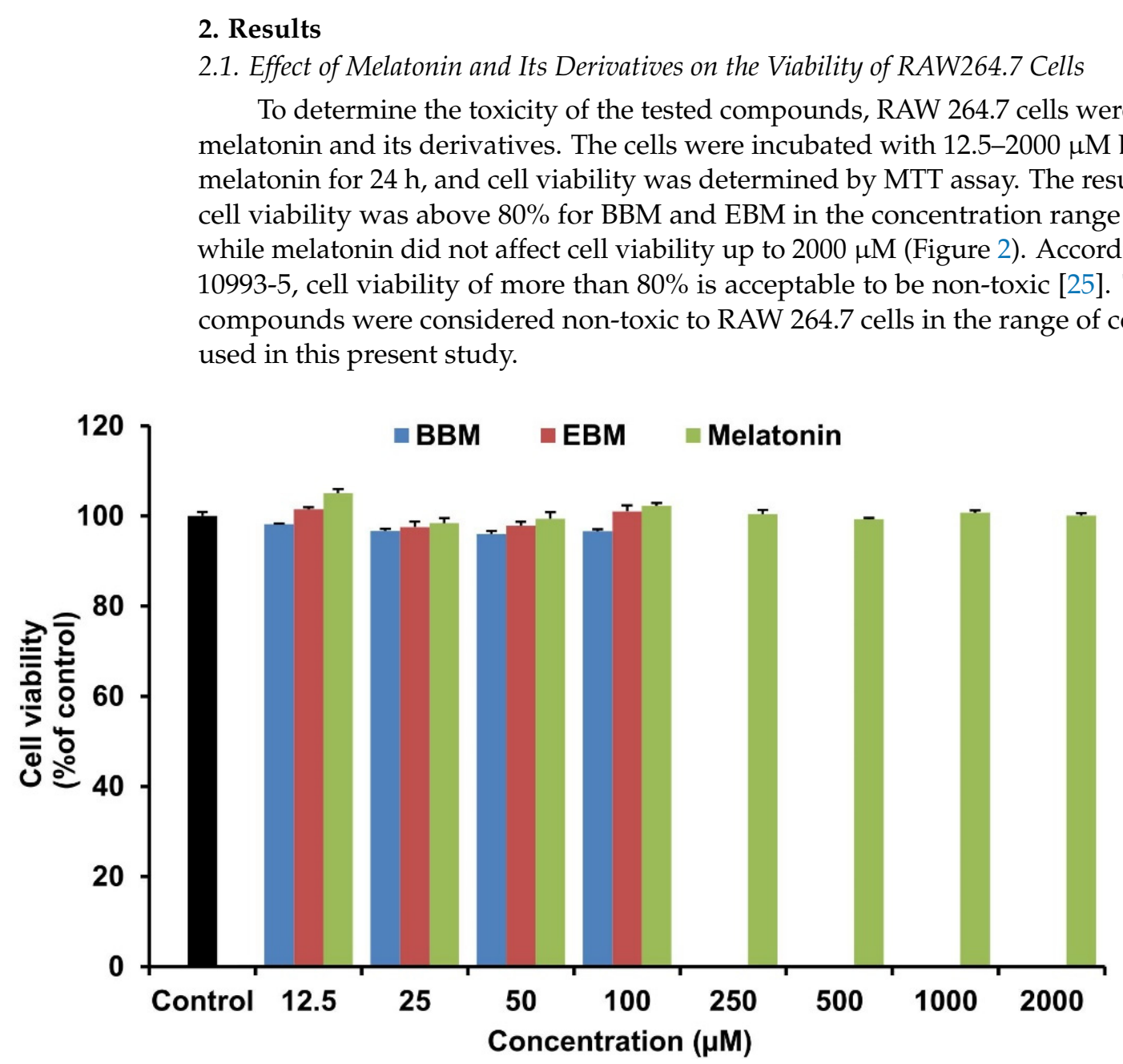

Figure 2. Viability of RAW 264.7 cells after treatment with melatonin, BBM, and EBM in various concentrations. The percentage cell viabilities were calculated relative to viability of the vehicle-treatment group. Values are expressed as means \pm S.E.M $(n=8)$.

2.2. Effect of Melatonin and Its Derivatives on NO Production in LPS-Stimulated RAW264.7 Cells

The production of NO was determined from the culture medium of LPS-stimulated RAW 264.7 cells. Cells were treated simultaneously with LPS and various concentrations of melatonin or its derivatives, BBM and EBM, for $24 \mathrm{~h}$. The production of NO was determined by Griess reagent. As shown in Figure 3, BBM and EBM inhibited LPSinduced NO production by RAW 264.7 cells at all tested concentrations $(6.25-100 \mu \mathrm{M})$ in a concentration dependent manner. Both modified derivatives had significantly higher potency in inhibiting the production of NO than melatonin, which suggests that NO production was influenced by the lipophilic substituents at both the N1- and N-acyl side chain positions. This was supported by the $\mathrm{IC}_{50}$ values of BBM, EBM, and MLT, which were $39.81,34.52$, and $>100 \mu \mathrm{M}$, respectively. 


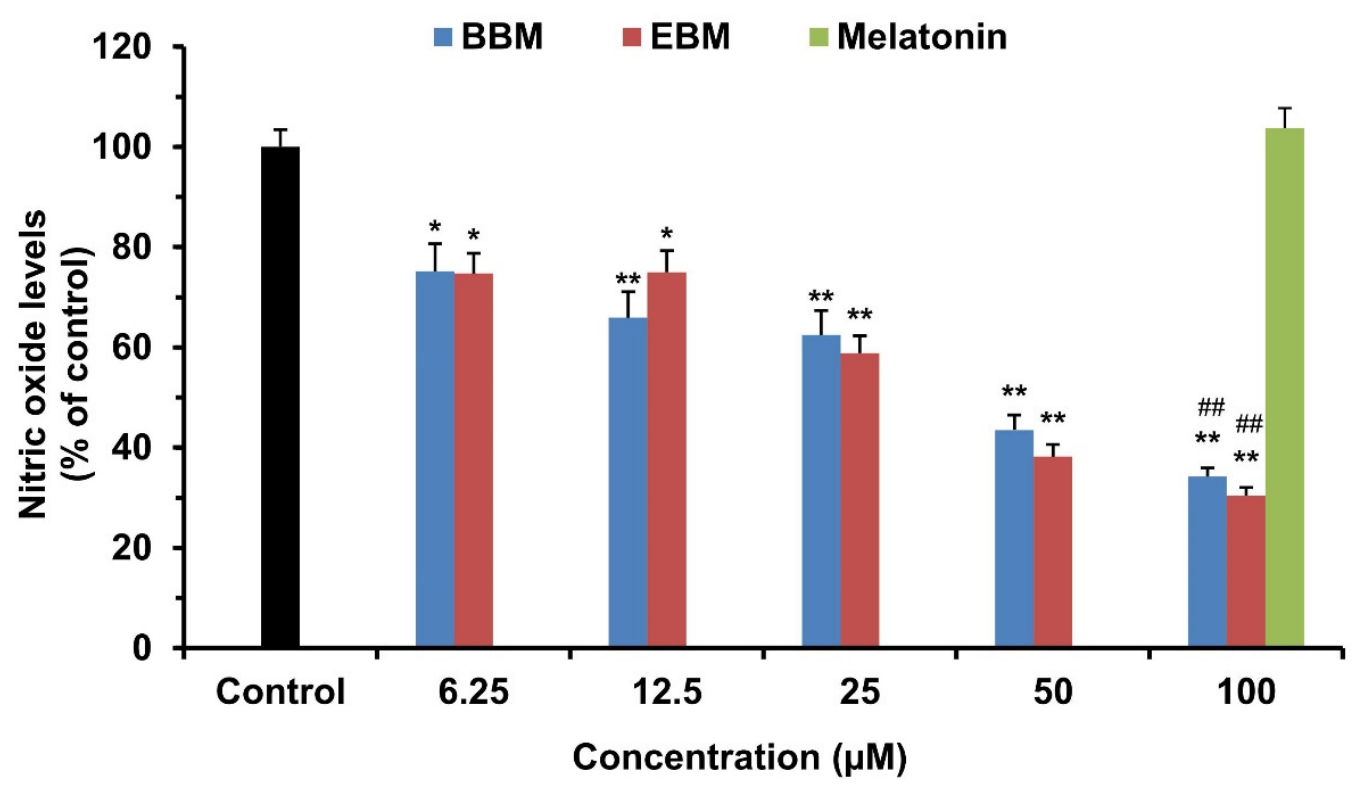

Figure 3. Effect of melatonin, BBM and EBM on the production of nitric oxide in LPS-stimulated RAW 264.7 cells. Values are expressed as the means \pm S.E.M ${ }^{*} p<0.05,{ }^{* *} p<0.001$ versus vehicle treatment group, $\# p<0.001$ versus melatonin $100 \mu \mathrm{M}$.

\subsection{Effect of Melatonin and Its Derivatives on PGE 2 Production in LPS-Stimulated RAW264.7 Cells}

In LPS-induced RAW246.7 macrophages, BBM and EBM significantly $(p<0.05)$ decreased the production of the proinflammatory mediator $\mathrm{PGE}_{2}$, at 6.25 and $12.5 \mu \mathrm{M}$, respectively (Figure 4). A comparison between melatonin and its modified derivatives at the same concentration $(100 \mu \mathrm{M})$ shows that the BBM and EBM derivatives had a higher inhibitory effect on the production of $\mathrm{PGE}_{2}$ than melatonin. Among the two derivatives, BBM exhibited the best activity with an $\mathrm{IC}_{50}$ value of $7.02 \mu \mathrm{M}$, whereas the EBM and melatonin $\mathrm{IC}_{50}$ values were 35.20 and $>100 \mu \mathrm{M}$, respectively.

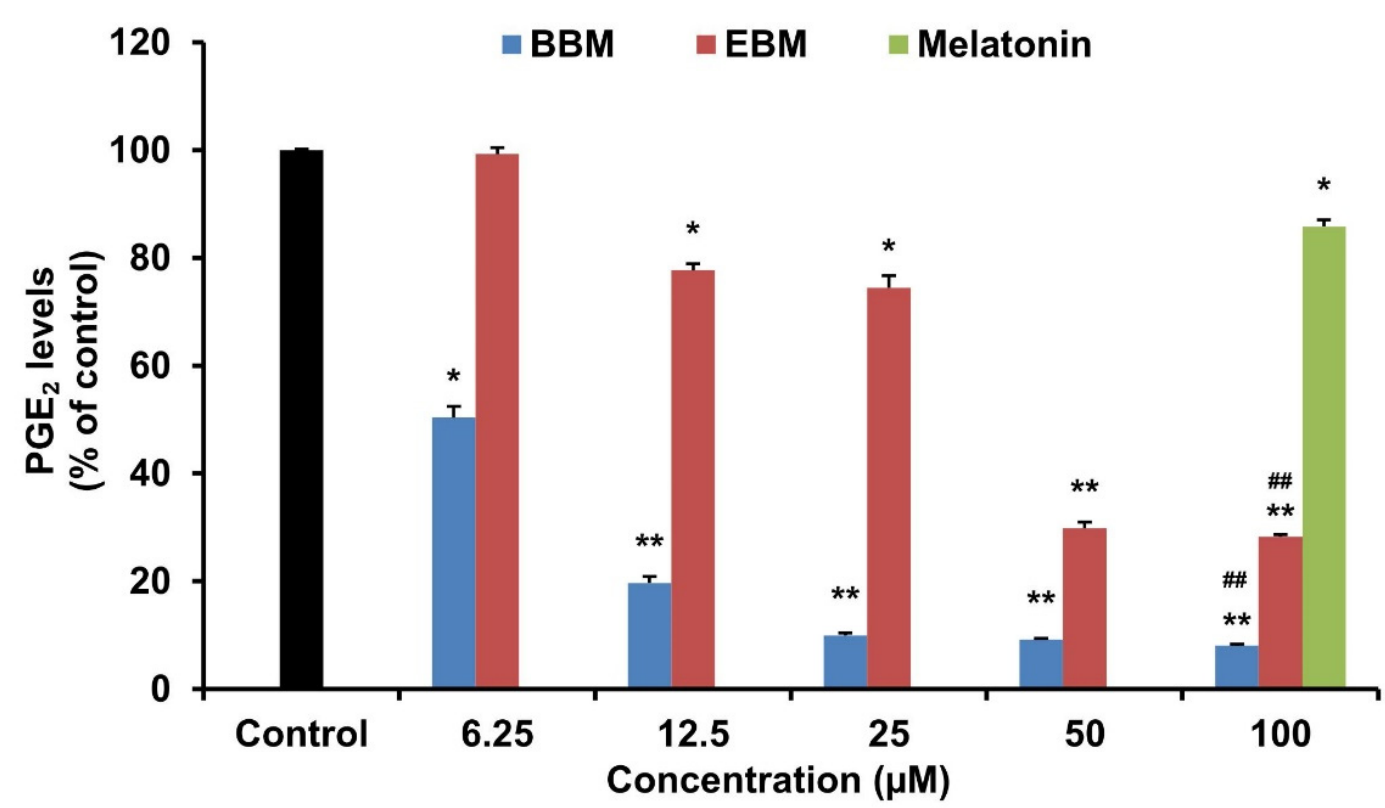

Figure 4. Effect of melatonin, BBM and EBM on the production of PGE $_{2}$ in LPS-stimulated RAW 264.7 cells. Values are expressed as the means \pm S.E.M ${ }^{*} p<0.05,{ }^{* *} p<0.001$ versus vehicle treatment group, $\# \# p<0.001$ versus melatonin $100 \mu \mathrm{M}$. 


\subsection{Effect of Melatonin and Its Derivatives on IL-6 and TNF- $\alpha$ Production in LPS-Stimulated RAW264.7 Cells}

The effect of melatonin and its derivatives on the production of pro-inflammatory cytokines, IL-6 and TNF- $\alpha$ were investigated in LPS-stimulated RAW 264.7 cells. LPSinduced IL-6 production was significantly suppressed by EBM from $25 \mu \mathrm{M}$, BBM from $50 \mu \mathrm{M}$ and melatonin at $100 \mu \mathrm{M}$ (Figure 5). Both derivatives reduced the level of IL-6 by more than their parent compound at $100 \mu \mathrm{M}$. EBM established the highest activity with an $\mathrm{IC}_{50}$ value of $71.03 \mu \mathrm{M}$, while melatonin and BBM both had $\mathrm{IC}_{50}$ values $>100 \mu \mathrm{M}$. Melatonin and its derivatives did not alter TNF- $\alpha$ levels in LPS-stimulated RAW 264.7 cells (Figure 6).

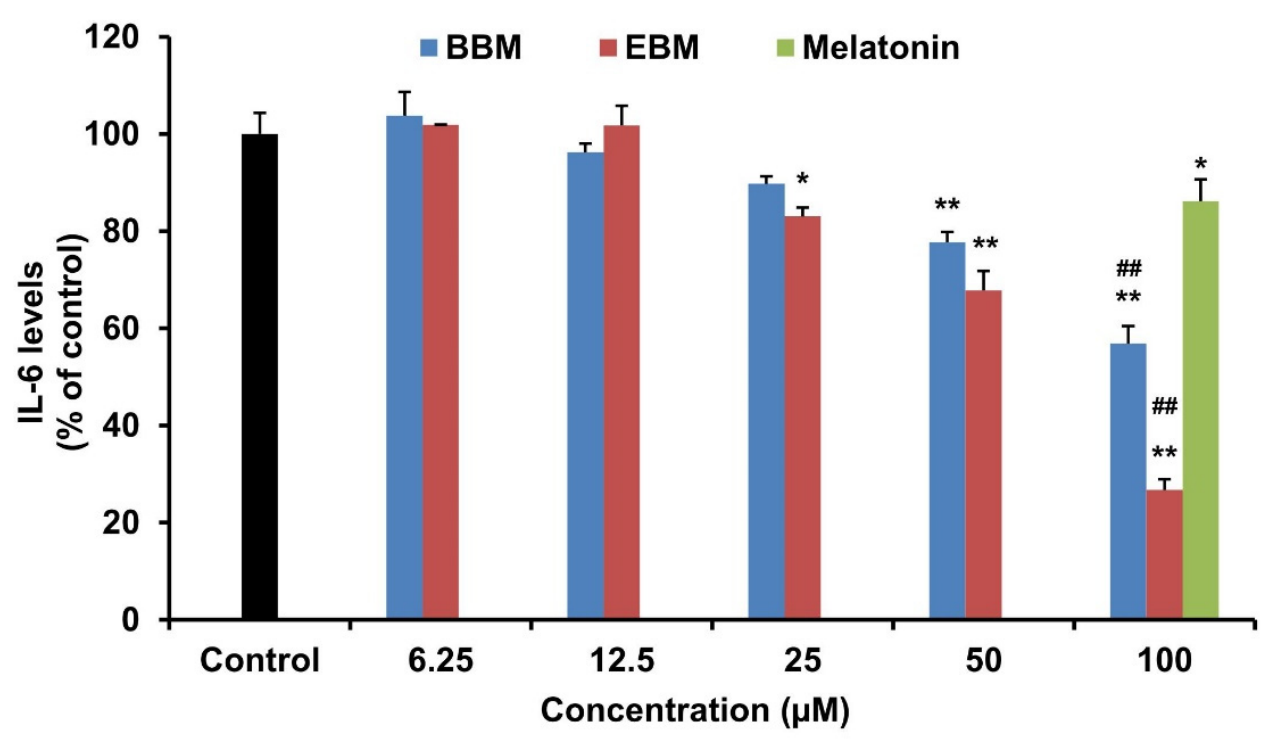

Figure 5. Effect of melatonin, BBM and EBM on the production of IL-6 in LPS-stimulated RAW 264.7 cells. Values are expressed as the means \pm S.E.M ${ }^{*} p<0.05,{ }^{* *} p<0.001$ versus vehicle treatment group, $\# p<0.001$ versus melatonin $100 \mu \mathrm{M}$.

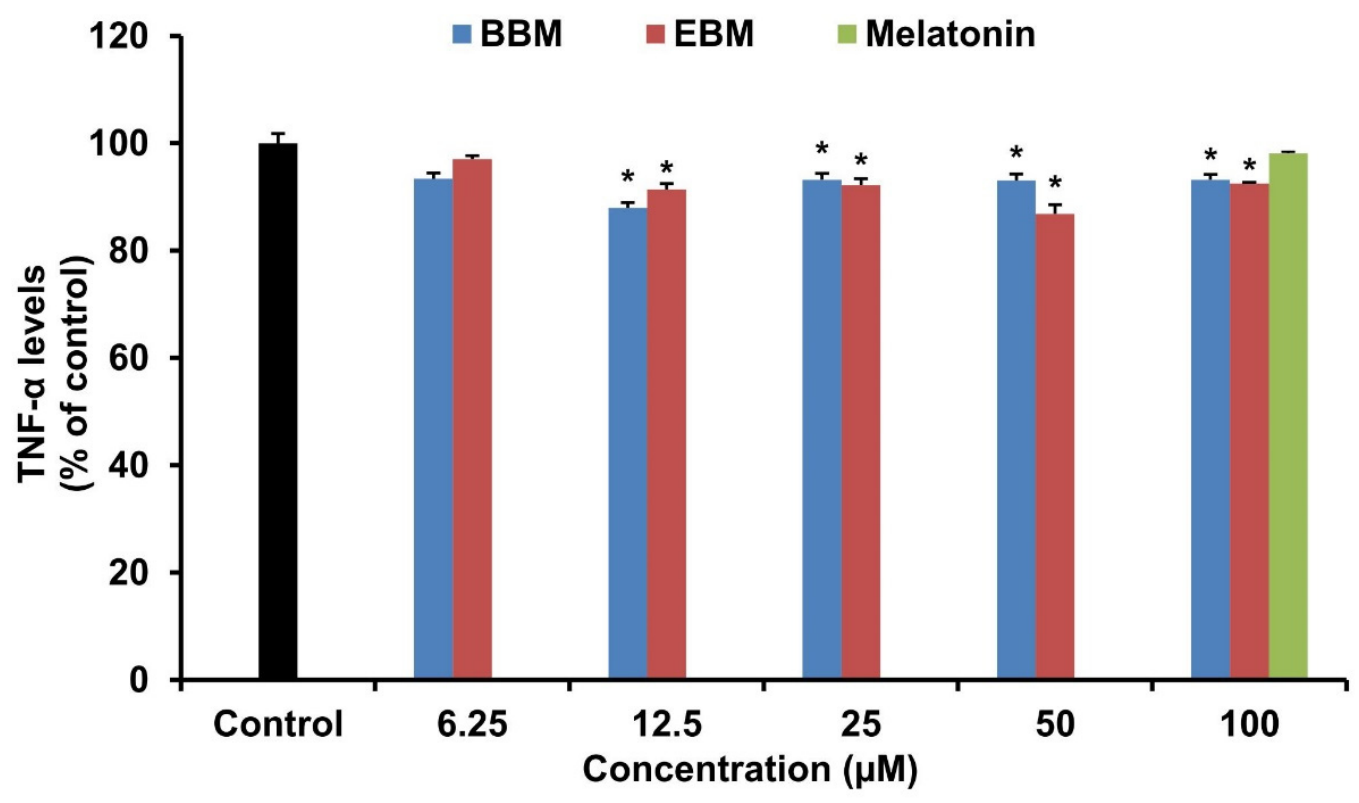

Figure 6. Effect of BBM and EBM on the production of TNF- $\alpha$ in LPS-stimulated RAW 264.7 cells. Values are expressed as the means \pm S.E.M ${ }^{*} p<0.05$ versus vehicle treatment group. 


\subsection{In Vivo Anti-Inflammatory Activity}

Croton oil-induced ear edema is an in vivo model widely used for investigation of topical acute anti-inflammatory activity. This model is rapid and simple. Moreover, it requires only a small amount of substance to perform this method [26]. Topical application of all tested compounds significantly decreased ear thickness at 1-4 $\mathrm{h}$ after exposure to croton oil. Aspirin, the positive control, inhibited mice ear edema by $63.6 \pm 5.8 \%$ at $1 \mathrm{~h}$ after application of croton oil and reached peak inhibition of $88.2 \pm 7.4 \%$ at $3 \mathrm{~h}$ (Table 1 ). Melatonin inhibited ear edema by a maximum of $76.9 \pm 10.3 \%$ at $4 \mathrm{~h}$ after exposure to croton oil. BBM inhibited edema by $65.0 \pm 12.0 \%$ after $2 \mathrm{~h}$ and $76.9 \pm 10.3 \%$ inhibition at $4 \mathrm{~h}$. Peak inhibition of ear edema by EBM was $69.2 \pm 9.7 \%$ at $4 \mathrm{~h}$.

Table 1. Ear thickness of mice ( $\mathrm{mm})$ and \% inhibition of croton oil-induced ear edema.

\begin{tabular}{|c|c|c|c|c|c|c|c|c|c|}
\hline \multirow{2}{*}{$\underset{\text { (h) }}{\operatorname{Time}}$} & \multirow{2}{*}{\begin{tabular}{|c|}
$\begin{array}{c}\text { Control } \\
\text { Group }\end{array}$ \\
$\begin{array}{c}\text { Thickness } \\
(\mathrm{mm})\end{array}$ \\
\end{tabular}} & \multicolumn{2}{|c|}{ Aspirin } & \multicolumn{2}{|c|}{ BBM } & \multicolumn{2}{|c|}{ EBM } & \multicolumn{2}{|c|}{ Melatonin } \\
\hline & & $\begin{array}{l}\text { Thickness } \\
\text { (mm) }\end{array}$ & $\begin{array}{c}\% \\
\text { Inhibition }\end{array}$ & $\begin{array}{l}\text { Thickness } \\
\text { (mm) }\end{array}$ & $\begin{array}{c}\% \\
\text { Inhibition }\end{array}$ & $\begin{array}{c}\text { Thickness } \\
(\mathrm{mm})\end{array}$ & $\begin{array}{c}\% \\
\text { Inhibition }\end{array}$ & $\begin{array}{c}\text { Thickness } \\
(\mathrm{mm})\end{array}$ & $\begin{array}{c}\% \\
\text { Inhibition }\end{array}$ \\
\hline Initial & $0.192 \pm 0.005$ & $0.193 \pm 0.003$ & - & $0.180 \pm 0.004$ & - & $0.183 \pm 0.006$ & - & $0.197 \pm 0.006$ & - \\
\hline 1 & $0.228 \pm 0.005$ & $0.207 \pm 0.002^{\mathrm{a}}$ & $63.6 \pm 5.8^{a}$ & $0.207 \pm 0.003^{a}$ & $27.3 \pm 9.1^{b}$ & $0.205 \pm 0.003^{a}$ & $40.9 \pm 10.9^{a}$ & $0.218 \pm 0.006$ & $40.9 \pm 4.6^{\mathrm{a}, \mathrm{b}}$ \\
\hline 2 & $0.225 \pm 0.004$ & $0.207 \pm 0.005^{\mathrm{a}}$ & $60.0 \pm 6.3^{a}$ & $0.192 \pm 0.004^{\mathrm{a}, \mathrm{b}, \mathrm{c}}$ & $65.0 \pm 12.0^{\mathrm{a}}$ & $0.200 \pm 0.005^{\mathrm{a}}$ & $50.0 \pm 10.0^{a}$ & $0.217 \pm 0.006$ & $40.0 \pm 11.0^{\mathrm{a}}$ \\
\hline 3 & $0.220 \pm 0.003$ & $0.197 \pm 0.004^{\mathrm{a}}$ & $88.2 \pm 7.4^{\mathrm{a}}$ & $0.187 \pm 0.004^{\mathrm{a}, \mathrm{c}}$ & $76.5 \pm 7.4^{\mathrm{a}}$ & $0.197 \pm 0.007^{\mathrm{a}}$ & $52.9 \pm 7.4^{\mathrm{a}, \mathrm{b}}$ & $0.203 \pm 0.006^{\mathrm{a}}$ & $76.5 \pm 11.8^{a}$ \\
\hline 4 & $0.213 \pm 0.003$ & $0.197 \pm 0.004^{\mathrm{a}}$ & $84.6 \pm 9.7^{\mathrm{a}}$ & $0.185 \pm 0.004^{\mathrm{a}, \mathrm{b}, \mathrm{c}}$ & $76.9 \pm 10.3^{\mathrm{a}}$ & $0.190 \pm 0.005^{\mathrm{a}}$ & $69.2 \pm 9.7^{\mathrm{a}}$ & $0.202 \pm 0.005^{\mathrm{a}}$ & $76.9 \pm 10.3^{a}$ \\
\hline
\end{tabular}

Note: ${ }^{\mathrm{a}, \mathrm{b}, \mathrm{c}} p<0.05$ versus no-treatment (control group), aspirin-treated and melatonin-treated groups, respectively.

\section{Discussion}

Macrophages are effector cells which play an important role in inflammatory processes. Activated macrophages produce pro-inflammatory cytokines such as IL-1 $\beta$, IL-6, and TNF- $\alpha$, as well as PGE 2 and NO [27]. RAW 264.7 murine macrophage cells have been widely used for in vitro anti-inflammatory studies. These cells are sensitive to LPS stimulation, which is an endotoxin isolated from gram negative bacteria [28]. LPS activates the nuclear factor kappa B (NF-kB) pathway, thus releasing pro-inflammatory cytokines [29]. According to the current study, RAW 264.7 macrophages exposed to LPS produced nitrite, which implied NO production. Our results show that NO production was significantly inhibited by BBM and EBM in a dose-dependent manner at concentrations as low as $6.25 \mu \mathrm{M}$. BBM and EBM exhibited significantly higher potency than melatonin at $100 \mu \mathrm{M}$. Interestingly, both the modified melatonin structures with the lipophilic substitutions at either the N1-indole ring or the $\mathrm{N}$-acyl side chain are better NO suppressors than the parent structure melatonin. It has been reported that anti-inflammatory actions of melatonin depend on the inhibition of the expression of iNOS and the efficiency of NO scavenging [5].

In addition to inhibition of NO production, melatonin and its derivatives also significantly inhibited the production of $\mathrm{PGE}_{2}$ and IL-6. Furthermore, both derivatives demonstrated higher potency than melatonin at the same concentration $(100 \mu \mathrm{M})$. This result correlates with previous reports that melatonin inhibited the expression of iNOS and COX2, both of which are key enzymes that catalyze the production of NO and PGEs [30-33]. Among the derivatives, $\mathrm{BBM}$ displayed the highest inhibitory effect on $\mathrm{PGE}_{2}$ production, and EBM had the highest inhibitory effect on IL-6. A previous report showed that the effect of modifying the $\mathrm{N}$-acetyl side chain of melatonin was to inhibit the production of NO, TNF- $\alpha$, IL-6, and pro-IL-1 $\beta$ in LPS-induced RAW 264.7 cells [7]. Taken together, this suggests that the production of NO, PGE 2 and IL- 6 are affected by modification at either the N1-position or the $N$-acetyl side chain of melatonin. In contrast, both derivatives only slightly affected TNF- $\alpha$ production.

NO, PGE 2 and IL- 6 are considered to be the most important mediators of inflammation both in vitro and in vivo $[34,35]$. Therefore, we employed the in vivo acute antiinflammatory model using a croton oil model to induce acute inflammation for investigation of topical anti-inflammatory agents. 12-O-tetradecanoylphorbol-13-acetate (TPA), the main irritant contained in croton oil, activates protein kinase $C$, which stimulates the re- 
lease of pro-inflammatory cytokines including IL-1 $\beta$, TNF- $\alpha$ and IL- 6 , and other mediators such as phospholipase A2 and arachidonic acid [36]. Leukotrienes and prostaglandins are arachidonic acid metabolites produced by 5-LOX and COX enzymes [37]. Shin et al. [38] indicated that application of croton oil increased expression of COX-1 and COX-2 and increased $\mathrm{PGE}_{2}$ production. These mechanisms increase vascular permeability, vasodilation and swelling due to the release of histamine and serotonin, which is followed by the synthesis of leukotrienes and prostaglandins [39]. Therefore, anti-inflammatory drugs such as aspirin that inhibit COX enzymes are effective in suppressing ear edema induced by croton oil [40,41]. Ear edema induced by croton oil peaks about $6 \mathrm{~h}$ after exposure [42]. Priprem et al. [43] reported that application of a melatonin gel reduced mouse ear edema $1 \mathrm{~h}$ after croton oil stimulation. Therefore, the present study decided to evaluate inhibition of ear edema after application of croton oil at $1-4 \mathrm{~h}$. The results showed that all tested compounds reduced mice ear edema volumes, measured as ear thickness. BBM showed a significantly reduced ear thickness compared to melatonin at $2-4 \mathrm{~h}$. Melatonin and BBM inhibited croton oil induced mice ear edema and reached a plateau of inhibition at 3-4 h, which was similar to aspirin. Interestingly, BBM dramatically inhibited mice ear edema (65\% inhibition) at $2 \mathrm{~h}$, while melatonin and EBM reached the edema inhibition $>65 \%$ at 3 and $4 \mathrm{~h}$, respectively. It is well-known that the lipophilic molecules are the preferred passive skin permeation. As results of in silico predictions (Supplementary Materials; Table S1), BBM was characterized as a high skin permeation $\left(\log K_{\mathrm{p}} ;-6.15\right)$ [44]. The presence of the bromobenzoylamide group at the N1-position of the melatonin structure could increase the lipophilicity $\left(\log P_{\mathrm{o} / \mathrm{w}} 3.36\right)$ and topological polar surface area (TPSA; $\left.60.33 \mathrm{~A}^{0}\right)$, which are the key parameters for absorption prediction [45].

The modified compound, BBM, showed similar acute anti-inflammatory effects to melatonin in vivo, but had greater NO, IL-6 and $\mathrm{PGE}_{2}$ suppressing effects in vitro. The rate-determining step of partitioning into the stratum corneum depends on the lipophilicity of the permeant molecules, whereas partitioning from the stratum corneum into the viable epidermis and dermis involves other physicochemical parameters, including solubility and dissociation, in addition to lipophilicity [44]. Despite similarities in the permeability coefficients of melatonin and BBM, the increased lipophilicity, molecular size and decreased water solubility of BBM potentially alters transport through the skin, affecting in vivo anti-inflammatory activity but not in vitro. Additionally, the anti-inflammatory effects of melatonin involve several pathways, 5-LOX, iNOS and COX-2 $[5,8,46,47]$ that should be thoroughly explored. Further investigations are essential to develop the potential applications of melatonin derivatives.

\section{Materials and Methods}

\subsection{Chemicals}

Melatonin was purchased from Shanghai Chemical Co. Ltd. (Shanghai, China). The melatonin derivatives, BBM and EBM, were synthesized and characterized by the Melatonin Research Group, Khon Kaen University, Thailand [20]. RPMI 1640, fetal bovine serum (FBS), antibiotic-antimycotic (100X), 5\% trypsin-EDTA, Dulbecco's phosphate-buffered saline (DPBS) 10X, and 0.4\% trypan blue stain were purchased from Gibco. Inc. (New York, NY, USA). Further, 3-(4, 5-dimethyl-2-thiazolyl)-2, 5-diphenyl-2H-tetrazolium bromide (MTT) was purchased from Invitrogen (Eugene, Oregon, USA). Lipopolysaccharides (LPS) from Escherichia coli 0111:B4, sulfanilamide and naphthylethylenediamine dihydrochloride (NED) were purchased from Sigma-Aldrich (St. Louis, MO, USA). Dimethyl sulfoxide (DMSO), and phosphoric acid and acetone were obtained from Fisher Chemical (Loughborough, UK). Mouse PGE 2 , IL-6, TNF- $\alpha$ ELISA kits were purchased from R\&D Systems, A Bio-Techne (Minneapolis, MN, USA). Aspirin and croton oil were purchased from SigmaAldrich (St. Louis, MO, USA). 


\subsection{Cell Culture}

The murine macrophage cells, RAW 264.7, were obtained from Cell Lines Service (Eppelheim, Germany) and cultured in RPMI 1640 medium supplemented with 10\% FBS and $1 \%$ antibiotic-antimycotic. Cells were incubated at $37^{\circ} \mathrm{C}$ and humidified with $5 \% \mathrm{CO}_{2}$ conditions. The medium culture was replaced every 2-3 days until the cells reached $80 \%$ confluence. Cells were counted by hemocytometer with Trypan blue staining.

\subsection{Cytotoxicity}

RAW 264.7 cells were seeded in 96-well plates at a density of $2 \times 10^{4}$ cells/well and incubated for $24 \mathrm{~h}$. The culture medium was then changed, and cells were treated with melatonin $(12.5-2000 \mu \mathrm{M})$, BBM or EBM $(12.5-100 \mu \mathrm{M})$ at concentrations dependent on their solubility, and incubated for another $24 \mathrm{~h}$. Cell viability was measured by MTT assay by incubation with $0.5 \mathrm{mg} / \mathrm{mL}$ of MTT solution for $4 \mathrm{~h}$. Formasan crystals were dissolved by DMSO, and the absorbance was determined at $550 \mathrm{~nm}$ by microplate reader (Ensight, Perkin Elmer Inc., Waltham, MA, USA). Cell viability was calculated, and the non-toxic concentrations were used in further experiments.

\subsection{In Vitro Anti-Inflammatory Activity}

\subsubsection{Determination of NO Production}

Nitrite accumulation was measured as an indicator of NO production. RAW 264.7 cells were seeded in 24-well plates for $24 \mathrm{~h}$ prior to incubation with melatonin, BBM or EBM in the presence of $1 \mu \mathrm{g} / \mathrm{mL}$ of LPS. After $24 \mathrm{~h}$ of incubation, the supernatant of cultured medium was collected to determine the NO production. The quantity of nitrite was measured as an indicator of NO production by using Griess reagent at the absorbance at $550 \mathrm{~nm}$. The Griess reagent was a mixture of $2 \%(w / v)$ of sulfanilamide and $0.2 \%(w / v)$ of NED in $2.5 \%$ phosphoric acid. The quantity of nitrite was determined from a sodium nitrite standard curve.

\subsubsection{Determination of PGE 2 , IL-6, and TNF- $\alpha$ Levels}

The supernatants of cultured medium were collected in the same way as the NO experiment. After stimulation with LPS and incubation with melatonin or its derivatives, supernatants of RAW 264.7 cells were collected to measure the PGE 2 , IL-6, or TNF- $\alpha$ levels by commercial ELISA kits following the manufacturer's instructions.

\subsection{In Vivo Anti-Inflammatory Activity}

\subsubsection{Animals}

Nine to twelve-week-old male ICR mice, weight 25-30 g, were purchased from Nomura Siam International Co, Ltd., Bangkok, Thailand. The mice were housed in groups of 6 per cage, with access to pellet food and water. The room was maintained at a $12 \mathrm{~h}$ light-dark cycle, and was $23 \pm 2{ }^{\circ} \mathrm{C}$ temperature controlled.

\subsubsection{Croton Oil-Induced Ear Edema}

Mice were randomly assigned into 6 per group. Melatonin, BBM or EBM solutions were prepared as $1 \%(w / v)$ in acetone. Ten $\mu \mathrm{L}$ of melatonin or its derivatives $(100 \mu \mathrm{g} /$ ear $)$ was applied to the left outer ears of the mice $30 \mathrm{~min}$ prior to applying $5 \%$ croton oil to the left inner ears. The thickness of ears was measured every $1 \mathrm{~h}$ to $4 \mathrm{~h}$. The inhibition of ear edema was calculated compared to the initial thickness. Acetone and $5 \%$ aspirin were used as negative and positive controls, respectively. The percentage of inhibition was calculated by the following Equation (1).

$$
\% \text { Inhibition of ear edema }=\left[\left(\Delta_{\text {Neg CTR }}-\Delta_{\text {Sample }}\right) / \Delta_{\text {Neg CTR }}\right] \times 100
$$

where $\Delta_{\mathrm{Neg}}$ CTR $=$ different of ear thickness at time ${ }_{\mathrm{n}}$ and initial time of negative control group, $\Delta_{\text {Sample }}=$ different of ear thickness at time $e_{n}$ and initial time of sample group. 


\subsection{Statistical Analysis}

Data are expressed as mean \pm standard error of mean (S.E.M). The statistics were analyzed using the one-way analysis of variance (ANOVA) followed by Tukey's post hoc test. The $p$-values less than $0.05(p<0.05)$ were considered statistically significant. The comparisons of ear thickness and inhibition of ear edema were conducted using the independent $t$-test. $p<0.05$ indicated statistically significant differences.

\section{Conclusions}

Two melatonin derivatives modified at the N1-position and the $\mathrm{N}$-acetyl side chain exhibited superior inhibition of the production of NO, $\mathrm{PGE}_{2}$ and IL-6 in LPS-induced inflammatory responses in macrophage RAW 264.7 cells compared to their parent melatonin. The 4-bromobenzoyl $\mathrm{N}$-substituted modified melatonin derivatives showed the same acute anti-inflammatory effect as melatonin in a croton oil-induced mouse ear edema model, but with improved pharmacokinetic parameters. Therefore, BBM appears to be a promising new anti-inflammatory agent, and further studies into its mechanism of action and pharmacokinetic properties are warranted.

Supplementary Materials: The following are available online. Figure S1. ${ }^{1} \mathrm{H}-\mathrm{NMR}$ spectrum of BBM. Figure S2. ${ }^{13} \mathrm{C}-\mathrm{NMR}$ spectrum of BBM. Figure S3. IR spectrum of BBM. Figure S4. ${ }^{1} \mathrm{H}-\mathrm{NMR}$ spectrum of EBM. Figure S5. ${ }^{13} \mathrm{C}$-NMR spectrum of EBM. Figure S6. IR spectrum of EBM, Table S1. MW, Lipophilicity values in Octanol-water (Log Po/w), topological polar surface area (TPSA), solubility parameter $(\log S)$, permeability coefficient $(\log K \mathrm{p})$ predicted from Swiss ADME.

Author Contributions: Conceptualization, P.P. (Ploenthip Puthongking), P.M.; methodology, P.S., P.P. (Ploenthip Puthongking), T.D., P.M., A.P.; formal analysis, P.S., P.P. (Ploenthip Puthongking), P.M.; investigation, P.S., P.P. (Ploenthip Puthongking), P.M.; resources, P.P. (Ploenthip Puthongking), P.M. and P.P. (Panyada Panyatip); writing — original draft preparation, P.S., P.P. (Ploenthip Puthongking), A.P.; writing-review and editing, P.S., P.P. (Ploenthip Puthongking), P.P. (Panyada Panyatip), T.D., P.M., A.P.; visualization, P.P. (Ploenthip Puthongking), P.M., A.P.; supervision, P.P. (Ploenthip Puthongking), P.M., A.P.; project administration, P.P. (Ploenthip Puthongking); funding acquisition P.P. (Ploenthip Puthongking), P.M. All authors have read and agreed to the published version of the manuscript.

Funding: This research was funded by Research and Academic Services, Khon Kaen University (Grant No. RP63002) and The Graduate School, Khon Kaen University for the Research Fund for Supporting Lecturer to Admit High Potential Student to Study and Research on His Expert Program (Grant No. 581H219).

Institutional Review Board Statement: This experiment was conducted in accordance with ethical approval obtained from the Institutional Animal Care and Use Committee of Khon Kaen University (Record No. IACUC-KKU 78/60).

Informed Consent Statement: Not applicable.

Data Availability Statement: The data presented in this study are available on request from the corresponding author.

Acknowledgments: The authors thank Glenn Borlace, Faculty of Pharmaceutical Sciences, Khon Kaen University, for English language assistance.

Conflicts of Interest: The authors declare no conflict of interest.

Sample Availability: Samples of melatonin and its derivatives are available from the authors.

\section{References}

1. Chen, L.; Deng, H.; Cui, H.; Fang, J.; Zuo, Z.; Deng, J.; Li, Y.; Wang, X.; Zhao, L. Inflammatory responses and inflammationassociated diseases in organs. Oncotarget 2017, 9, 7204-7218. [CrossRef] [PubMed]

2. Hawkins, P.; Stephens, L. PI3K signalling in inflammation. Biochim. Biophys. Acta (BBA)-Mol. Cell Biol. Lipids 2015, 1851, 882-897. [CrossRef]

3. Galano, A.; Tan, D.X.; Reiter, R.J. On the free radical scavenging activities of melatonin's metabolites, AFMK and AMK. J. Pineal Res. 2013, 54, 245-257. [CrossRef] 
4. Mauriz, J.L.; Collado, P.S.; Veneroso, C.; Reiter, R.J.; González-Gallego, J. A review of the molecular aspects of melatonin's anti-inflammatory actions: Recent insights and new perspectives. J. Pineal Res. 2013, 54, 1-14. [CrossRef] [PubMed]

5. Mayo, J.C.; Sainz, R.M.; Tan, D.-X.; Hardeland, R.; Leon, J.; Rodriguez, C.; Reiter, R.J. Anti-inflammatory actions of melatonin and its metabolites, N1-acetyl-N2-formyl-5-methoxykynuramine (AFMK) and N1-acetyl-5-methoxykynuramine (AMK), in macrophages. J. Neuroimmunol. 2005, 165, 139-149. [CrossRef]

6. Esposito, E. Antiinflammatory Activity of Melatonin in Central Nervous System. Curr. Neuropharmacol. 2010, 8, 228-242. [CrossRef]

7. Shim, D.-W.; Shin, H.J.; Han, J.-W.; Ji, Y.-E.; Jang, C.-H.; Koppula, S.; Kang, T.-B.; Lee, K.-H. A novel synthetic derivative of melatonin, 5-hydroxy-2'-isobutyl-streptochlorin (HIS), inhibits inflammatory responses via regulation of TRIF-dependent signaling and inflammasome activation. Toxicol. Appl. Pharmacol. 2015, 284, 227-235. [CrossRef] [PubMed]

8. Deng, W.-G.; Tang, S.-T.; Tseng, H.-P.; Wu, K.K. Melatonin suppresses macrophage cyclooxygenase-2 and inducible nitric oxide synthase expression by inhibiting p52 acetylation and binding. Blood 2006, 108, 518-524. [CrossRef] [PubMed]

9. Cuzzocrea, S.; Costantino, G.; Mazzon, E.; Caputi, A.P. Regulation of prostaglandin production in carrageenan-induced pleurisy melatonin. J. Pineal Res. 1999, 27, 9-14. [CrossRef]

10. Yu, C.-X.; Zhu, C.-B.; Xu, S.-F.; Cao, X.-D.; Wu, G.-C. Selective MT2 melatonin receptor antagonist blocks melatonin-induced antinociception in rats. Neurosci. Lett. 2000, 282, 161-164. [CrossRef]

11. El-Shenawy, S.M.; Abdel-Salam, O.M.; Baiuomy, A.R.; El-Batran, S.; Arbid, M. Studies on the anti-inflammatory and antinociceptive effects of melatonin in the rat. Pharmacol. Res. 2002, 46, 235-243. [CrossRef]

12. Harpsøe, N.G.; Andersen, L.P.H.; Gögenur, I.; Rosenberg, J. Clinical pharmacokinetics of melatonin: A systematic review. Eur. J. Clin. Pharmacol. 2015, 71, 901-909. [CrossRef]

13. Zetner, D.; Andersen, L.; Rosenberg, J. Pharmacokinetics of Alternative Administration Routes of Melatonin: A Systematic Review. Drug Res. 2016, 66, 169-173. [CrossRef] [PubMed]

14. Waldhauser, F.; Waldhauser, M.; Lieberman, H.R.; Deng, M.-H.; Lynch, H.J.; Wurtman, R.J. Bioavailability of Oral Melatonin in Humans. Neuroendocrinology 1984, 39, 307-313. [CrossRef]

15. Tordjman, S.; Najjar, I.; Bellissant, E.; Anderson, G.M.; Barburoth, M.; Cohen, D.; Jaafari, N.; Schischmanoff, O.; Fagard, R.; Lagdas, E.; et al. Advances in the Research of Melatonin in Autism Spectrum Disorders: Literature Review and New Perspectives. Int. J. Mol. Sci. 2013, 14, 20508-20542. [CrossRef]

16. Shirinzadeh, H.; Eren, B.; Gurer-Orhan, H.; Suzen, S.; Özden, S. Novel Indole-Based Analogs of Melatonin: Synthesis and in Vitro Antioxidant Activity Studies. Molecules 2010, 15, 2187-2202. [CrossRef] [PubMed]

17. Thoại, P.V.; Nam, N.H. Design and Synthesis of Sustain-Acting Melatonin Prodrugs. J. Chem. 2013, 2013, 1-6. [CrossRef]

18. Phiphatwatcharaded, C.; Topark-Ngarm, A.; Puthongking, P.; Mahakunakorn, P. Anti-Inflammatory Activities of Melatonin Derivatives in Lipopolysaccharide-Stimulated RAW 264.7 Cells and Antinociceptive Effects in Mice. Drug Dev. Res. 2014, 75, 235-245. [CrossRef]

19. Elmegeed, G.A.; Baiuomy, A.R.; Abdel-Salam, O. Evaluation of the anti-inflammatory and anti-nociceptive activities of novel synthesized melatonin analogues. Eur. J. Med. Chem. 2007, 42, 1285-1292. [CrossRef] [PubMed]

20. Panyatip, P.; Johns, N.P.; Priprem, A.; Nakagawa, K.; Puthongking, P. Effect of N-Amide Substitution on Antioxidative Activities of Melatonin Derivatives. Sci. Pharm. 2020, 88, 3. [CrossRef]

21. Mor, M.; Silva, C.; Vacondio, F.; Plazzi, P.V.; Bertoni, S.; Spadoni, G.; Diamantini, G.; Bedini, A.; Tarzia, G.; Zusso, M.; et al. Indolebased analogs of melatonin: In vitro antioxidant and cytoprotective activities. J. Pineal Res. 2004, 36, 95-102. [CrossRef] [PubMed]

22. Panyatip, P.; Nunthaboot, N.; Puthongking, P. In Silico ADME, Metabolism Prediction and Hydrolysis Study of Melatonin Derivatives. Int. J. Tryptophan Res. 2020, 13, 1-7. [CrossRef] [PubMed]

23. Panyatip, P.; Tadtong, S.; Sousa, E.; Puthongking, P. BACE1 Inhibitor, Neuroprotective, and Neuritogenic Activities of Melatonin Derivatives. Sci. Pharm. 2020, 88, 58. [CrossRef]

24. Fan, X.; Li, J.; Deng, X.; Lu, Y.; Feng, Y.; Ma, S.; Wen, H.; Zhao, Q.; Tan, W.; Shi, T.; et al. Design, synthesis and bioactivity study of $\mathrm{N}$-salicyloyl tryptamine derivatives as multifunctional agents for the treatment of neuroinflammation. Eur. J. Med. Chem. 2020, 193, 112217. [CrossRef]

25. ISO. ISO-10993-5. Biological Evaluation of Medical Devices, Part 5: Tests for In Vitro Cytotoxicity, 3rd ed.; ISO Central Secretariat: Geneva, Switzerland, 2009.

26. Gábor, M. Models of acute inflammation in the ear. In Inflammation Protocols, 1st ed.; Winyard, P.G., Willoughby, D.A., Eds.; Humana Press: Totowa, NJ, USA, 2003; Volume 225, pp. 129-137.

27. Liu, T.; Zhang, L.; Joo, D.; Sun, S.-C. NF-kB signaling in inflammation. Signal Transduct. Target Ther. 2017, 2, 17023. [CrossRef]

28. Chang, C.-Y.; Tucci, M.; Baker, R.C. Lipopolysaccharide-stimulated nitric oxide production and inhibition of cell proliferation is antagonized by ethanol in a clonal macrophage cell line. Alcohol 2000, 20, 37-43. [CrossRef]

29. Muniandy, K.; Gothai, S.; Badran, K.M.H.; Kumar, S.S.; Esa, N.M.; Arulselvan, P. Suppression of Proinflammatory Cytokines and Mediators in LPS-Induced RAW 264.7 Macrophages by Stem Extract of Alternanthera sessilis via the Inhibition of the NF- $\mathrm{kB}$ Pathway. J. Immunol. Res. 2018, 2018, 1-12. [CrossRef]

30. Ricciotti, E.; FitzGerald, G.A. Prostaglandins and inflammation. Arterioscler. Thromb. Vasc. Biol. 2011, 31, 986-1000. [CrossRef] [PubMed]

31. Sales, K.J.; Jabbour, H.N. Cyclooxygenase enzymes and prostaglandins in pathology of the endometrium. Reproduction 2003, 126, 559-567. [CrossRef] 
32. Gilad, E.; Wong, H.; Zingarelli, B.; Virág, L.; O'Connor, M.; Salzman, A.L.; Szabó, C. Melatonin inhibits expression of the inducible isoform of nitric oxide synthase in murine macrophages: Role of inhibition of NFKB activation. FASEB J. 1998, 12, 685-693. [CrossRef] [PubMed]

33. Tamura, E.K.; Cecon, E.; Monteiro, A.W.A.; Silva, C.L.M.; Markus, R.P. Melatonin inhibits LPS-induced NO production in rat endothelial cells. J. Pineal Res. 2009, 46, 268-274. [CrossRef] [PubMed]

34. Wright, T.M. Cytokines in acute and chronic inflammation. Front. Biosci. 1997, 2, 12-26. [CrossRef]

35. Taki, N.; Tatro, J.M.; Lowe, R.; Goldberg, V.M.; Greenfield, E.M. Comparison of the roles of IL-1, IL-6, and TNF $\alpha$ in cell culture and murine models of aseptic loosening. Bone 2007, 40, 1276-1283. [CrossRef]

36. Pinto, N.D.C.C.; Machado, D.C.; da Silva, J.M.; Conegundes, J.L.M.; Gualberto, A.C.M.; Gameiro, J.; Chedier, L.M.; Castañon, M.C.M.N.; Scio, E. Pereskia aculeata Miller leaves present in vivo topical anti-inflammatory activity in models of acute and chronic dermatitis. J. Ethnopharmacol. 2015, 173, 330-337. [CrossRef] [PubMed]

37. Wang, H.Q.; Kim, M.P.; Tiano, H.F.; Langenbach, R.; Smart, R.C. Protein Kinase C- $\alpha$ Coordinately Regulates Cytosolic Phospholipase A2 Activity and the Expression of Cyclooxygenase-2 through Different Mechanisms in Mouse Keratinocytes. Mol. Pharmacol. 2001, 59, 860-866. [CrossRef] [PubMed]

38. Shin, S.; Joo, S.S.; Park, D.; Jeon, J.H.; Kim, T.K.; Kim, J.S.; Park, S.K.; Hwang, B.Y.; Kim, Y.-B. Ethanol extract of Angelica gigas inhibits croton oil-induced inflammation by suppressing the cyclooxygenase-prostaglandin pathway. J. Vet. Sci. 2010, 11, 43-50. [CrossRef] [PubMed]

39. Barbosa, A.G.; Oliveira, C.D.; Lacerda-Neto, L.J.; Vidal, C.S.; Saraiva, R.D.A.; Da Costa, J.G.; Coutinho, H.D.; Galvao, H.B.; De Menezes, I.R. Evaluation of chemical composition and antiedematogenic activity of the essential oil of Hyptis martiusii Benth. Saudi J. Biol. Sci. 2017, 24, 355-361. [CrossRef]

40. Subramanian, B.; Kuo, F.; Ada, E.; Kotyla, T.; Wilson, T.; Yoganathan, S.; Nicolosi, R. Enhancement of anti-inflammatory property of aspirin in mice by a nano-emulsion preparation. Int. Immunopharmacol. 2008, 8, 1533-1539. [CrossRef]

41. Vane, J.; Botting, R. The mechanism of action of aspirin. Thromb. Res. 2003, 110, 255-258. [CrossRef]

42. Tubaro, A.; Dri, P.; Melato, M.; Mulas, G.; Bianchi, P.; Del Negro, P.; Della Loggia, R. In the croton oil ear test the effects of non steroidal antiinflammatory drugs (NSAIDs) are dependent on the dose of the irritant. Inflamm. Res. 1986, 19, 371-373. [CrossRef]

43. Priprem, A.; Netweera, V.; Mahakunakorn, P.; Johns, N.P.; Johns, J.R. Prolonged Anti-Inflammatory Activity of Topical Melatonin by Niosomal Encapsulation. Adv. Mater. Res. 2014, 902, 70-75. [CrossRef]

44. Ottaviani, G.; Martel, S.; Carrupt, P.-A. In Silico and In Vitro Filters for the Fast Estimation of Skin Permeation and Distribution of New Chemical Entities. J. Med. Chem. 2007, 50, 742-748. [CrossRef] [PubMed]

45. Ertl, P.; Rohde, B.; Selzer, P. Fast Calculation of Molecular Polar Surface Area as a Sum of Fragment-Based Contributions and Its Application to the Prediction of Drug Transport Properties. J. Med. Chem. 2000, 43, 3714-3717. [CrossRef]

46. Steinhilber, D.; Brungs, M.; Werz, O.; Wiesenberg, I.; Danielsson, C.; Kahlen, J.P.; Nayeri, S.; Schräder, M.; Carlberg, C. The nu-clear receptor for melatonin represses 5-lipoxygenase gene expression in human B lymphocytes. J. Biol. Chem. 1995, 270, 7037-7040. [CrossRef] [PubMed]

47. Shi, D.; Xiao, X.; Wang, J.; Liu, L.; Chen, W.; Fu, L.; Xie, F.; Huang, W.; Deng, W. Melatonin suppresses proinflammatory mediators in lipopolysaccharide-stimulated CRL1999 cells via targeting MAPK, NF-kB, c/EBP $\beta$, and p300 signaling. J. Pineal Res. 2012, 53, 154-165. [CrossRef] 